Article

\title{
Detection of Genomic Regions Associated with Resistance to Stem Rust in Russian Spring Wheat Varieties and Breeding Germplasm
}

\author{
Irina N. Leonova ${ }^{1, *}$, Ekaterina S. Skolotneva ${ }^{1}$, Elena A. Orlova ${ }^{1}$, Olga A. Orlovskaya ${ }^{2}$ \\ and Elena A. Salina ${ }^{1}$ \\ 1 The Federal Research Center Institute of Cytology and Genetics SB RAS, 630090 Novosibirsk, Russia; \\ skolotnevaES@bionet.nsc.ru (E.S.S.); orlovaea@bionet.nsc.ru (E.A.O.); salina@bionet.nsc.ru (E.A.S.) \\ 2 Institute of Genetics and Cytology of the National Academy of Sciences of Belarus, 220072 Minsk, Belarus; \\ flaxol@tut.by \\ * Correspondence: leonova@bionet.nsc.ru; Fax: +7-(383)-333-12-78
}

Received: 17 June 2020; Accepted: 28 June 2020; Published: 1 July 2020

\begin{abstract}
Stem rust caused by Puccinia graminis f. sp. tritici Eriks. is a dangerous disease of common wheat worldwide. Development and cultivation of the varieties with genetic resistance is one of the most effective and environmentally important ways for protection of wheat against fungal pathogens. Field phytopathological screening and genome-wide association study (GWAS) were used for assessment of the genetic diversity of a collection of spring wheat genotypes on stem rust resistance loci. The collection consisting of Russian varieties of spring wheat and introgression lines with alien genetic materials was evaluated over three seasons (2016, 2017 and 2018) for resistance to the native population of stem rust specific to the West Siberian region of Russia. The results indicate that most varieties displayed from moderate to high levels of susceptibility to P. graminis; $16 \%$ of genotypes had resistance or immune response. In total, 13,006 single-nucleotide polymorphism (SNP) markers obtained from the Infinium $15 \mathrm{~K}$ array were used to perform genome-wide association analysis. GWAS detected 35 significant marker-trait associations (MTAs) with SNPs located on chromosomes 1A, 2A, 2B, 3B, 5A, 5B, 6A, 7A and 7B. The most significant associations were found on chromosomes 7A and $6 \mathrm{~A}$ where known resistance genes $\mathrm{Sr} 25$ and $S r 6 A i=2$ originated from Thinopyrum ssp. are located. Common wheat lines containing introgressed fragments from Triticum timopheevii and Triticum kiharae were found to carry Sr36 gene on 2B chromosome. It has been suggested that the quantitative trait loci (QTL) mapped to the chromosome 5BL may be new loci inherited from the T. timopheevii. It can be inferred that a number of Russian wheat varieties may contain the Sr17 gene, which does not currently provide effective protection against pathogen. This is the first report describing the results of analysis of the genetic factors conferring resistance of Russian spring wheat varieties to stem rust.
\end{abstract}

Keywords: wheat; Triticum aestivum; Puccinia graminis; introgression lines; GWAS; Sr genes

\section{Introduction}

Stem rust of wheat caused by the biotrophic fungus Puccinia graminis f. sp. tritici Erikss. \& Henning $(P g t)$ is one of the highly devastating diseases of cereals, which results in the destruction of susceptible plants under conditions favorable for the development of the infection. The distribution area, race composition and virulence of the pathogen vary significantly depending on the region of wheat cultivation and climate features. A historically significant spread and harmfulness of the pathogen have been observed in North and South America, Australia, Africa and China [1,2]. However, in the second half of the 20th century, the deleterious effect of stem rust in these countries decreased. This was due to the creation of new wheat varieties with genetic resistance to stem rust [3]. Measures 
developed for destruction of barberry as an intermediate host in the pathogen development cycle also had a significant impact [4].

Over the past two decades, the epidemiological situation regarding this disease has deteriorated significantly. Epidemics and sporadic outbreaks of stem rust are currently recorded in Western Europe [5]. The emergence of a new aggressive $P g t$ race Ug99, rapidly spreading across the African continent, resulted in crop losses of up to 80-100\% [6]. The Ug99 race and its biotypes (Ug99+ Sr36 and Ug99 + Sr24) are now registered in 13 countries: Egypt, Ethiopia, Eritrea, Iran, Kenya, Mozambique, Rwanda, Sudan, South Africa, Tanzania, Uganda, Yemen and Zimbabwe [7-9].

In the Russian Federation, stem rust was extremely rare in the regions of the North Caucasus and the Volga region, while the disease was focal and had no significant economic consequence. Currently, the pathogen distribution area has expanded, and crop damage is observed in almost all regions of Russia [10-12]. This is largely due to climate changes, pathogen migration dynamics, the emergence of new virulence races and the loss of resistance of wheat varieties to Pgt. Monitoring of the race composition of the stem rust in the Central region of Russia showed a significant diversity of $P$. graminis with the dominance of highly virulent pathotypes [13]. Strong development of stem rust, close to epiphytotic, has been observed since 2016 in the Republic of Tatarstan, while all wheat cultivars recommended for cultivation in the region turned out to be susceptible to the pathogen [14].

The Ural and West Siberian regions are the largest producers of spring bread wheat, which accounts for more than $40 \%$ of the acreage. However, despite the tendency to increase the productivity, there is a variation in the yield over the years, which largely depends on the resistance of commercial wheat cultivars to fungal diseases. In the Ural and Siberian regions, stem rust was not registered previously, but, since 2008, it is observed annually. In the past few years, pathogen development in certain areas has reached the level of epiphytoty with crop damage up to $80 \%$ and yield reduction up to $30-40 \%[12,15,16]$. A pronounced increase in the pathogen virulence and aggressiveness has been observed in recent years in Northern Kazakhstan, adjacent to the West Siberian region [17].

In connection with the change in the phytosanitary status for stem rust in the Siberian region, constant monitoring of the race composition of the Pgt population and assessment of the susceptibility of wheat varieties recommended for cultivation in the region are required. The study and monitoring of the stem rust race composition in the Siberian region was launched in 2016. A comparison of the race biotypes of pathogens from different areas of Western Siberia suggests the existence of the Omsk and Altai subpopulations of $P$. graminis. At the same time, wheat crop areas in the Novosibirsk region are located in the migration zone between subpopulations and their mixing [18].

The development and use of resistant wheat varieties should be preceded by an analysis of the genetic basis of resistance. Currently, more than 80 stem rust (Sr) resistance genes have been identified in the genome of common wheat and wheat relatives [19]. The effectiveness of these genes in relation to local Pgt populations and Ug99 biotypes was evaluated [20-22]. Molecular markers for the identification of $\mathrm{Sr}$ genes and for marker-assisted selection (MAS) were developed (https://maswheat.ucdavis.edu/). The emergence of new virulent pathotypes, as well as the loss of efficiency of known Sr genes, generate a need for finding new sources of resistance for stem rust control.

The dynamic development of the West Siberian population of the fungus and the features of its race composition emphasize the importance for screening of wheat varieties and the search for donors of resistance loci. The aim of this work was to study a collection consisting of cultivars and breeding lines of spring bread wheat and promising common wheat introgression lines (ILs) with alien genetic material. The collection was not previously characterized by susceptibility to the stem rust pathogen and there is no information on the genetic factors that could determine disease resistance. 


\section{Results}

\subsection{Phenotyping}

Weather conditions during the years of testing were favorable for the development of stem rust infection. In 2016 and 2017, the first symptoms of the infection were recorded at the beginning of the second decade of July; in 2018, the infection appeared only at the end of the third decade of July, when early ripening varieties entered the stage of milky ripeness. The severity rating (SR) of the universally susceptible cultivar Chernyava-13 was 60MS-70S (Table S1) on the Cobb's scale, suggesting that the infection level was sufficient for a clear scoring of plant response. Analysis of variance (ANOVA) performed over three years of testing showed significant differences among genotypes and years of evaluation (Table 1).

Table 1. Analysis of variance of stem rust resistance in spring wheat genotypes.

\begin{tabular}{cccccc}
\hline & DF & SS & MS & F value & $p$ \\
\hline Genotype & 159 & 491.447 & 3.110 & 2.846 & 0.000000 \\
\hline Environment & 2 & 23.258 & 11.629 & 10.639 & 0.000034 \\
\hline Error & 318 & 345.409 & 1.093 & & \\
\hline
\end{tabular}

The analysis of the distribution of the infection patterns over the three seasons showed that on average $54 \%$ of the genotypes exhibited a highly and moderately susceptible types of the reaction (SR > 10MS-5S), while 16\% were resistant genotypes (SR < 10R) (Figure 1 and Table S1). According to monitoring data, the pathogen background in different areas of Western Siberia was higher during 2016-2017 and the infection appeared much earlier [12,18]. It resulted in a three-fold increase in the number of susceptible genotypes compared to 2018. It is necessary to emphasize the peculiarities of the development of stem rust in the region, which consist in a low degree of severity rating (SR $>10-30 \%$ ) and a highly sensitive type of the reaction. It is due to an early decrease in the average daily temperature and the transition of the fungus to a stage of teliospores, which are unable to further infect wheat.
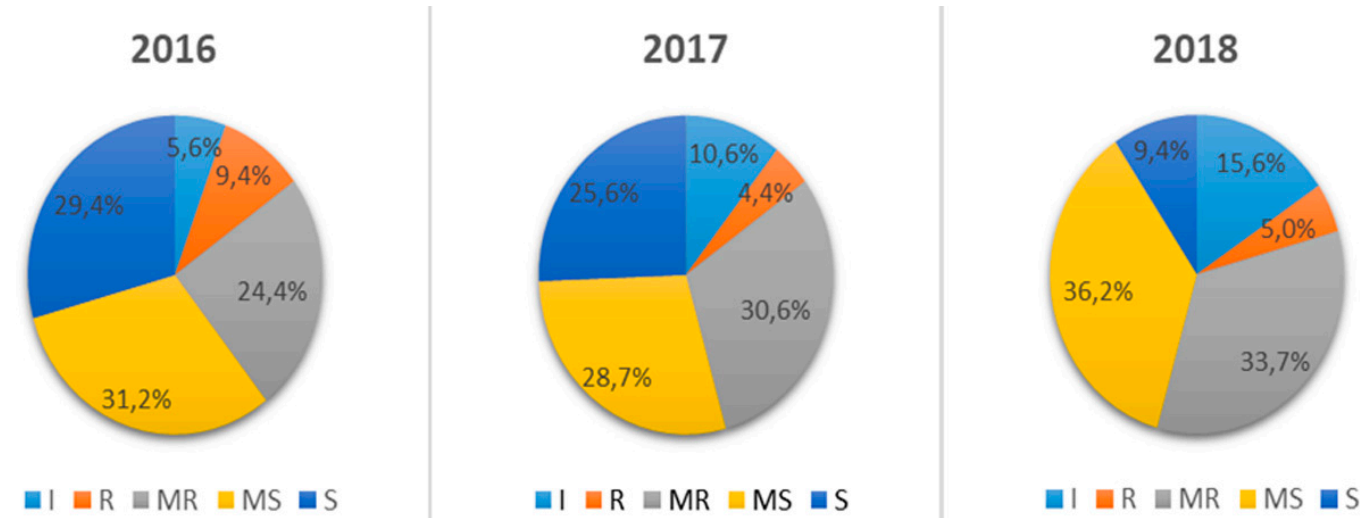

Figure 1. Diagram of distribution of spring wheat varieties by susceptibility to stem rust during 2016-2018.

The comparison of the severity ratings of commercial varieties and introgression lines showed that the number of genotypes characterized by a resistant type of the reaction was significantly higher among ILs (Figure 2a,b). Thus, the immune and resistant (IT =0/R) types of the reaction in all three years displayed $49 \%$ of ILs and only $15 \%$ of wheat cultivars and breeding lines. 


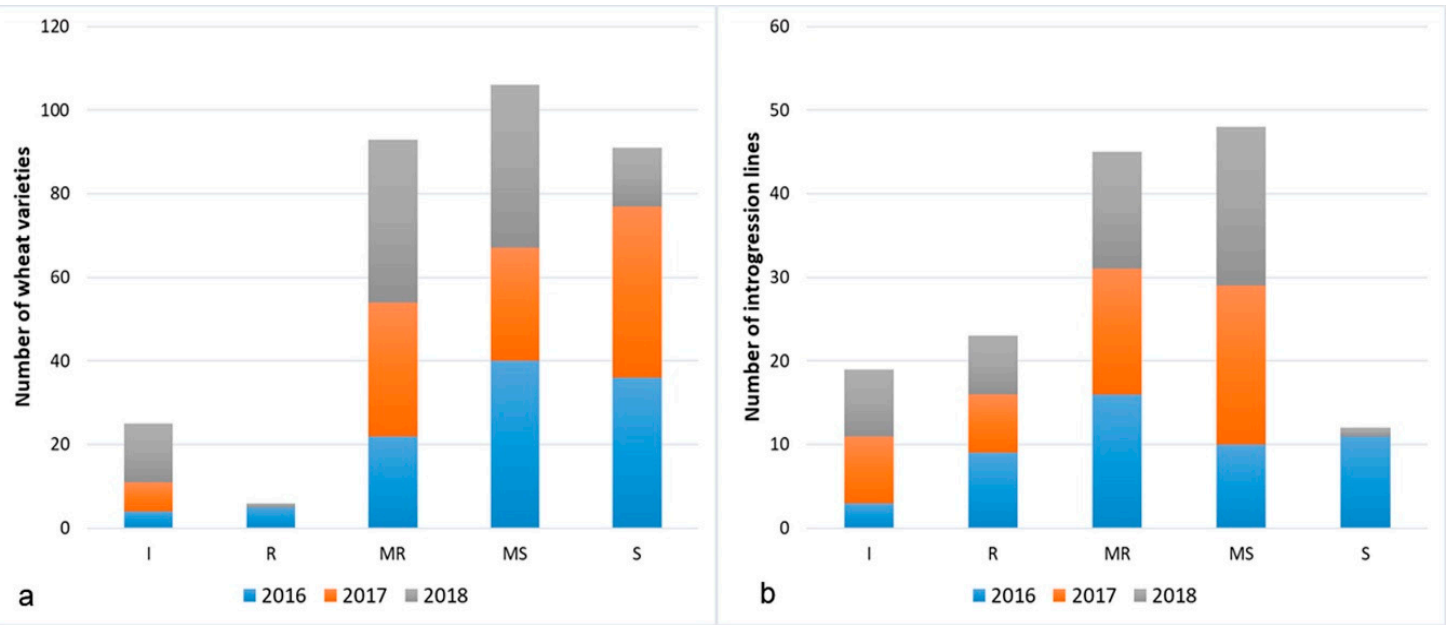

Figure 2. Frequencies of wheat varieties (a) and introgression lines (b) in different infection types to stem rust pathogen.

\subsection{Genetic Population Structure}

Four thousand eight hundred SNP markers covering all chromosomes of common wheat were used to determine the genetic population structure. Based on the results obtained using the STRUCRURE and $\Delta K$ statistics, there were seven postulated subclusters, including $6,24,35,9,35,21$ and 28 genotypes, respectively (Figure 3 and Table S2).

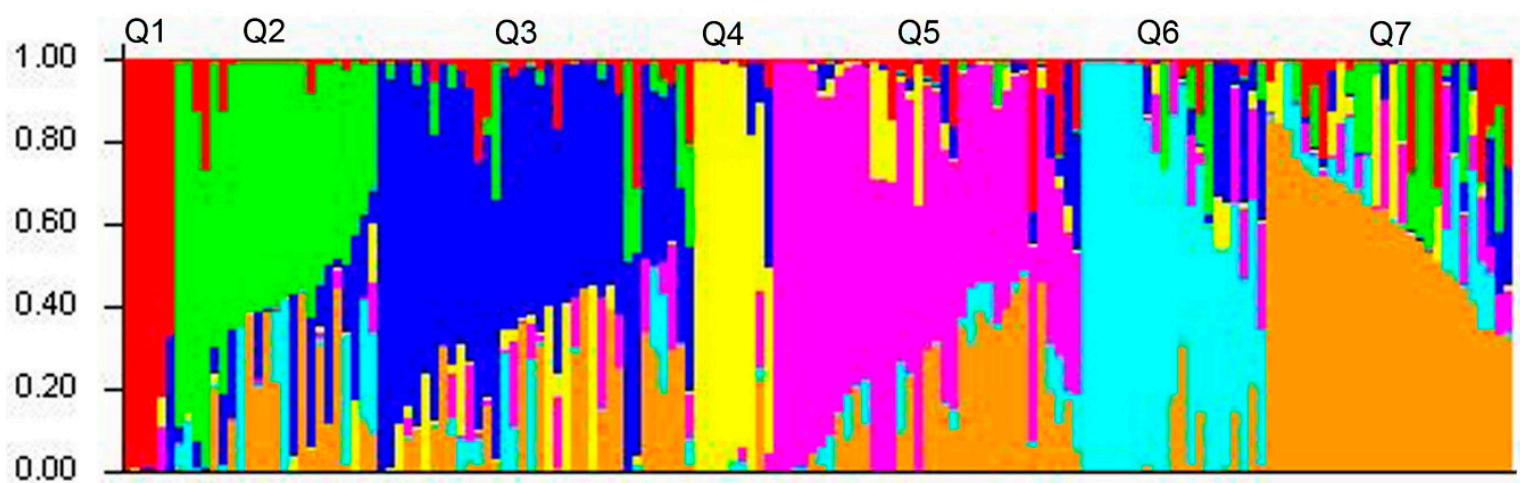

Figure 3. The population structure of spring wheat varieties calculated based on genotyping using 4800 SNP markers. The list of the genotypes belonging to the individual subpopulation is presented in Table S2.

Clusters 1 and 4 included T. aestivum/T. timopheevii introgression lines obtained by hybridization with wheat varieties Tselinnaya-20 and Irtyshanka-10, respectively. Clusters 2 and 7 consisted of Russian wheat varieties developed in various Russian breeding companies. Clusters 3 and 6 consisted mainly of Russian varieties; besides, ILs Saratovskaya-29/T. timopheevii and Novosibirskaya-67/T. timopheevii combined with three and six subpopulations, respectively. A set of ILs obtained with the participation of T. durum, T. dicoccum, T. dicoccoides and T. kiharae, as well as the original parental forms, grouped in Cluster 5. The dendrogram of genetic similarity, which was constructed using the complete set of SNP markers by the method of nearest neighbors, largely supported the results from the Bayesian-based clustering (Figure S1).

\subsection{Marker-Trait Association Study}

For genotyping of plant material, 13,006 SNP markers were used; after filtering, the number of markers for association mapping was 10,924 (Table S3). The number of markers mapped to different 
chromosomes of the A, B or D genomes varied significantly; the smallest one was observed for the fourth homoeological group. To perform the genome-wide association study, the mixed linear model (MLM) was used, which took into account the population structure $(\mathrm{Q})$ and kinship $(\mathrm{K})$. The quantile-quantile plot, illustrating the correspondence between the observed and expected $p$-values for MLM, is shown in Figure S2. Association mapping revealed 84 marker-trait associations (MTAs) for resistance to stem rust. The most informative SNPs $(p<0.005)$ were combined in nine QTLs on chromosomes 1A, 2A, 2B, $3 \mathrm{~B}, 5 \mathrm{~A}, 5 \mathrm{~B}, 6 \mathrm{~A}, 7 \mathrm{~A}$ and $7 \mathrm{~B}$ according to consensus genetic maps of wheat $[23,24]$ (Table 2 and Figure 4 ).

Significant associations on chromosomes $6 \mathrm{~A}$ and $6 \mathrm{D}$ were detected in five varieties: Tulaikovskaya-zolotistaya, Tulaikovskaya-10, Lutescens-101, Kinelskaya-60 and Volgouralskaya. It should be noted that the favorable allele of the marker wsnp_Ra_c5346_9501281 $\left(p=7.02 \times 10^{-4}\right)$ was amplified only in the genomes of three cultivars (Tulaikovskaya-zolotistaya, Tulaikovskaya-10 and Lutescens-101), while the favorable alleles Tdurum_contig75595_586 $\left(p=1.01 \times 10^{-3}\right)$ and Excalibur_rep_c99143_422 $\left(p=2.36 \times 10^{-3}\right)$ mapped at 6AS and 6DS were found in all five varieties (Table 2).
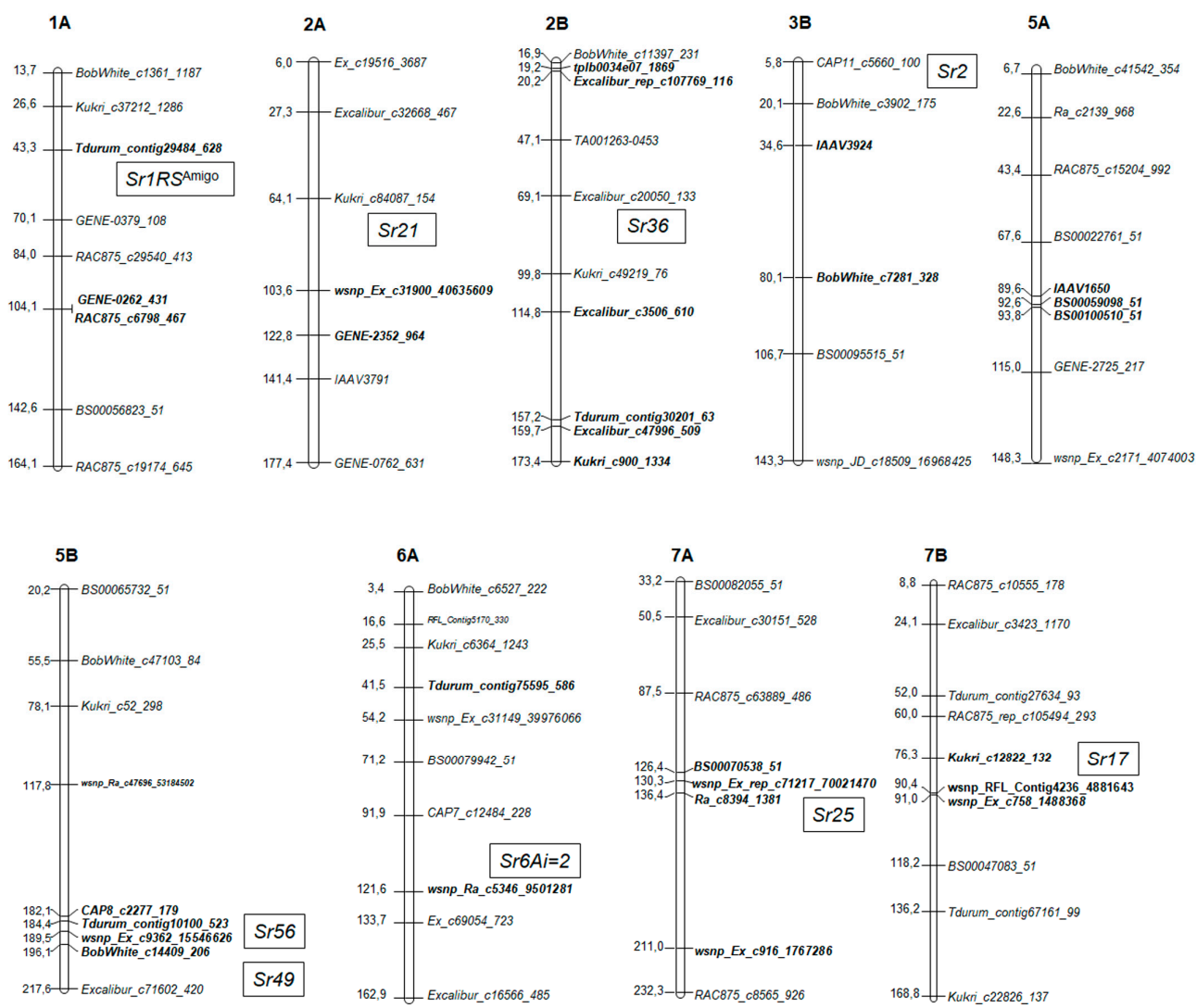

Figure 4. Schematic illustration of the localization of loci determining resistance to stem rust in wheat genotypes. Markers identified in this paper are indicated in bold. The order of the markers corresponds to the consensus chromosome maps for the SNP [23]. Known Sr resistance genes were added at the right side of the chromosomes according to published data [19]. 
Table 2. Marker-trait associations for stem rust resistance in spring bread wheat genotypes.

\begin{tabular}{|c|c|c|c|c|c|c|}
\hline SNP Marker & $\mathrm{Chr}^{*}$ & Allele & Distance * & $p$ & $\mathbf{R}^{2}$ & Genotype \\
\hline GENE-0262_431 & \multirow{3}{*}{$1 \mathrm{~A}$} & $\mathrm{~A} / \mathrm{G}$ & 104.145 & $3.67 \times 10^{-4}$ & 0.192 & \multirow{3}{*}{ Ustya, Omskaya-20, Priirtyshskaya-86, Pitic-62, Rybinskaya-127, Katyusha, Tarskaya-6, Tertsiya } \\
\hline RAC875_c6798_467 & & G/A & 104.145 & $1.15 \times 10^{-3}$ & 0.164 & \\
\hline Tdurum_contig29484_628 & & $\mathrm{C} / \mathrm{T}$ & 43.27 & $2.37 \times 10^{-3}$ & 0.129 & \\
\hline wsnp_Ex_c31900_40635609 & \multirow{2}{*}{$2 \mathrm{~A}$} & $\mathrm{C} / \mathrm{A}$ & 103.62 & $1.69 \times 10^{-3}$ & 0.152 & ILs $(821,832,837,842,157,38,67,94,140,199,676,25-2,34-1,15-7)$, T. timopheevii, T. kiharae, T. dicoccoides \\
\hline GENE-2352_964 & & G/A & 122.82 & $1.88 \times 10^{-3}$ & 0.150 & ILs $(206-2,213-1,226-7,25-2,34-1,16-5)$, Pitic-62, T. kiharae \\
\hline wsnp_Ex_c20169_29215401 & \multirow{8}{*}{$2 \mathrm{~B}$} & $\mathrm{~A} / \mathrm{C}$ & nd & $9.24 \times 10^{-4}$ & 0.158 & \multirow{8}{*}{ ILs (T. aestivum/T. timopheevii, 25-2), T. timopheevii, T. kiharae } \\
\hline tplb0034e07_1869 & & $\mathrm{C} / \mathrm{T}$ & 19.15 & $2.81 \times 10^{-3}$ & 0.201 & \\
\hline Excalibur_rep_c107769_116 & & $\mathrm{A} / \mathrm{G}$ & 20.16 & $1.63 \times 10^{-3}$ & 0.168 & \\
\hline Kukri_c46621_143 & & $\mathrm{T} / \mathrm{C}$ & 88.86 & $2.62 \times 10^{-4}$ & 0.245 & \\
\hline wsnp_Ex_c20169_29215401 & & $\mathrm{C} / \mathrm{A}$ & nd & $1.08 \times 10^{-3}$ & 0.238 & \\
\hline Excalibur_c47996_509 & & $\mathrm{A} / \mathrm{G}$ & 159.65 & $1.13 \times 10^{-3}$ & 0.201 & \\
\hline Tdurum_contig30201_63 & & $\mathrm{G} / \mathrm{T}$ & 157.21 & $3.43 \times 10^{-3}$ & 0.159 & \\
\hline Kukri_C900_1334 & & $\mathrm{T} / \mathrm{C}$ & 173.35 & $2.63 \times 10^{-3}$ & 0.169 & \\
\hline BobWhite_c7281_328 & \multirow{2}{*}{$3 \mathrm{~B}$} & $\mathrm{C} / \mathrm{T}$ & 80.12 & $1.87 \times 10^{-3}$ & 0.143 & \multirow{2}{*}{$\begin{array}{l}\text { Tulaikovskaya-1, Lutescens-85, Lutescens-148, Altaiskaya-530, Erythrospermum-72, Novosibirskaya-22, } \\
\text { Lutescens-25, Obskaya-14, Krasa-2, Rybinskaya-127, Pitic-62, ILs (213-1, 221-1, 34-1, 16-5) }\end{array}$} \\
\hline IAAV3924 & & $\mathrm{C} / \mathrm{T}$ & 34.61 & $3.27 \times 10^{-3}$ & 0.187 & \\
\hline Ra_c14657_919 & \multirow{3}{*}{$5 \mathrm{~A}$} & $\mathrm{~A} / \mathrm{G}$ & nd & $1.12 \times 10^{-3}$ & 0.201 & \multirow{3}{*}{ Rybinskaya-127, Pitic-62, ILs (221-1, 16-5), T. dicoccoides } \\
\hline BS00059098_51 & & $\mathrm{C} / \mathrm{A}$ & 92.60 & $2.63 \times 10^{-3}$ & 0.193 & \\
\hline BS00100510_51 & & $\mathrm{G} / \mathrm{T}$ & 93.75 & $3.23 \times 10^{-3}$ & 0.196 & \\
\hline wsnp_EX_c9362_15546626 & \multirow{4}{*}{$5 \mathrm{~B}$} & G/A & 189.51 & $2.24 \times 10^{-5}$ & 0.245 & \multirow{4}{*}{$\begin{array}{l}\text { ILs (Saratovskaya-29/T. timopheevi, Skala/T. timopheevii, Novosibirskaya-67/T. timopheevii, 34-1, 25-2), T. timopheevii, } \\
\text { T. kiharae }\end{array}$} \\
\hline Tdurum_contig10100_523 & & G/A & 184.39 & $4.43 \times 10^{-5}$ & 0.231 & \\
\hline wsnp_Ra_c47696_53184502 & & $\mathrm{A} / \mathrm{G}$ & 117.85 & $6.49 \times 10^{-4}$ & 0.200 & \\
\hline BobWhite_c14409_206 & & $\mathrm{T} / \mathrm{C}$ & 196.08 & $7.11 \times 10^{-4}$ & 0.209 & \\
\hline wsnp_Ra_5346_9501281 & \multirow{2}{*}{$6 \mathrm{~A}$} & $\mathrm{~T} / \mathrm{C}$ & 121.61 & $7.02 \times 10^{-4}$ & 0.203 & Tulaikovskaya-zolotistaya, Tulaikovskaya-10, Lutescens-101 \\
\hline Tdurum_contig75595_586 & & G/A & 41.46 & $1.01 \times 10^{-3}$ & 0.174 & \multirow{2}{*}{ Tulaikovskaya-zolotistaya, Tulaikovskaya-10, Kinelskaya-60, Volgouralskaya, Lutescens-101 } \\
\hline Excalibur_rep_c99143_422 & $6 \mathrm{D}$ & $\mathrm{C} / \mathrm{A}$ & 22.96 & $2.36 \times 10^{-3}$ & 0.156 & \\
\hline Ra_c8394_1381 & \multirow{4}{*}{$7 \mathrm{~A}$} & $\mathrm{~A} / \mathrm{G}$ & 136.43 & $6.86 \times 10^{-5}$ & 0.129 & \multirow{4}{*}{ Tulaikovskaya-belozernaya, Kinelskaya-60, Volgouralskaya, Erythrospermum-72, Albidum-73, Srada-Sibiri } \\
\hline BS00070538_51 & & $\mathrm{T} / \mathrm{C}$ & 126.4 & $2.78 \times 10^{-4}$ & 0.192 & \\
\hline wsnp_Ex_rep_c71217_70021470 & & $\mathrm{C} / \mathrm{A}$ & 130.27 & $9.79 \times 10^{-4}$ & 0.124 & \\
\hline wsnp_Ex_c916_1767286 & & $\mathrm{C} / \mathrm{T}$ & 211.00 & $9.38 \times 10^{-4}$ & 0.168 & \\
\hline wsnp_RFL_Contig4236_4881643 & \multirow{3}{*}{$7 \mathrm{~B}$} & G/A & 90.36 & $2.69 \times 10^{-3}$ & 0.191 & \multirow{3}{*}{$\begin{array}{l}\text { Altaiskii-prostor, Obskaya-14, Polushko, Baganskaya-93, Rybinskaya-127, Salimovka, Nostalgiya, Ustya, } \\
\text { Zlatozara, Obskaya-2 }\end{array}$} \\
\hline wsnp_Ex_c758_1488368 & & $\mathrm{C} / \mathrm{T}$ & 91.02 & $2.85 \times 10^{-3}$ & 0.189 & \\
\hline Kukri_c12822_132 & & G/A & 76.3 & $4.72 \times 10^{-3}$ & 0.114 & \\
\hline
\end{tabular}

${ }^{*}$ Chromosomal localization and marker position on the chromosome are indicated according to the consensus maps of T. aestivum L. [23,24]; favorable alleles are highlighted in bold; $\mathrm{R}^{2}$ indicates phenotypic variation explained by the significant locus. 
At the long arm of chromosome 7A, QTL was identified, which is associated with the resistance of varieties Tulaikovskaya-belozernaya, Tulaikovskaya-1, Volgouralskaya, Kinelskaya-60, Erithrospermum-72, Albidum-73 and Strada-Sibiri. Three SNPs (Ra_c8394_1381, BS00070538_51 and wsnp_Ex_rep_c71217_70021470) are located in the range from 126.40 to $136.43 \mathrm{cM}$; the wsnp_Ex_c916_1767286 $\left(p=9.38 \times 10^{-4}\right)$ occupies the position $211.00 \mathrm{cM}$ at the distal part of the long arm (Figure 4). Minor QTL was detected at the long arm of chromosome 7B in the range of 76-91 cM on consensus map. Favorable alleles of three SNP markers (wsnp_RFL_Contig4236_4881643 and wsnp_Ex_c758_1488368, Kukri_c12822_132) with a probability of $p<0.00269-0.00358$ were found in wheat varieties Altaiskii-prostor, Obskaya-14, Polyushko, Baganskaya-93, Rybinskaya-127, Salimovka, Nostalgiya, Ustya, Zlatozara and Obskaya-2.

Markers GENE_0262_431, RAC875_c6798_467 and Tdurum_contig29484_628 that showed association with resistance to stem rust were located at short arm of $1 \mathrm{~A}$ chromosome. Favorable alleles amplified in the genome of eight wheat varieties (Ustya, Omskaya-20, Priirtyshskaya-86, Pitic-62, Rybinskaya-127, Katyusha, Tarskaya-6 and Tertsiya) (Table 2). Reliable MTAs were found for nine SNP markers mapped to chromosome 2B. Three SNPs (tplb0034e071869, Excalibur_rep_c107769_116 and Kukri_c46621_143) are mapped in the regions of 19.15-20.16 cM and 88.86 of the short arm; four markers are localized on the long arm, three of these SNPs (Excalibur_c47996_509, Tdurum_contig30201_63 and Kukri_c900_1334) was mapped in the range from 157.21 to 173.35 cM. For markers wsnp_Ex_c20169_29215401 and wsnp_Exc20169_29215401, the exact positions on the chromosome are unknown. Favorable alleles were recorded in all T. aestivum/T. timopheevii introgression lines, in line 25-2, containing the genetic material of T. kiharae, and in parental wheats T. timopheevii and T. kiharae (Table 2).

On chromosome 5BL, five reliable MTAs were detected in the region from 182.14 to $196.08 \mathrm{cM}$. All SNP markers amplify favorable alleles in line 25-2, in most T. aestivum/T. timopheevii ILs, with the exception of the lines derived from the variety Irtyshanka-10. The genetic locus on chromosome $5 \mathrm{AL}$ contributes to the resistance of ILs 221-1 (T. durum/Belorusskaya 80), 16-5 (T. dicoccoides/Festivalnaya), varieties Pitic-62 and Rybinskaya-127. This is evidenced by reliable MTAs for SNP markers BS00059098_51, BS00100510_51, IAAV1650 mapped in the region 89.56-93.75 cM, and marker Ra_c14657_919 with an unknown position at the chromosome.

Associations with resistance response have been established on 2AL chromosome for two SNPs: the favorable allele wsnp_Ex_c31900_40635609 was detected in ILs with T. timopheevii genetic material, while resistance allele of GENE-2352_964 was amplified in lines 206-2, 213-1, 226-7, 25-2, 34-1 and 16-5, obtained by hybridization with T. kiharae and T. dicoccoides. Minor marker-trait associations were identified for the BobWhite_c7281_328 and IAAV3924 markers mapped to the short arm of 3B chromosome in the regions of 80.12 and $34.61 \mathrm{cM}$, respectively (Figure 4). Favorable alleles were amplified in the genomes of 11 wheat varieties and 4 ILs (Table 2).

\section{Discussion}

Little is known about the genetic resistance to stem rust in Russian bread wheat varieties thus far. Meanwhile, there is an urgent need to search for new sources and donors of stem rust resistance genes. Studies for identification of $\mathrm{Sr}$ genes were performed primarily on collections of synthetic wheats containing the Ae. tauschii genome and common wheat lines with introgressions from Aegilops ssp. [12,15,22]. The screening carried out in these studies using molecular markers designed for known Sr genes showed that the genotypes contain mainly the Sr25, Sr31, Sr24 and Sr17 genes and their combinations. In this study, the genetic diversity of $S r$ loci was estimated in the germplasm of spring wheat varieties suitable for release in Western Siberia. Screening material was extended with introgression lines containing the genetic material from the species of Triticeae tribe.

To search for stem rust resistance loci, genome-wide association study was applied, which allowed identifying QTLs on chromosomes 1A, 2A, 2B, 3B, 6A, 5A, 5B, 7A and 7B. At present, GWAS is an effective method for assessing the genetic diversity of crops on disease resistance genes, for studying 
the genetic architecture of agronomically important traits and for determining the chromosomal localization of valuable genes and quantitative trait loci [25-28]. Employing this approach, it is possible to analyze large size populations using the results obtained in different environments $[29,30]$. GWAS allows us to postulate the presence of both known resistance genes and previously unidentified loci. For example, new loci of resistance to stem rust, including Ug99, were found with SNP genotyping of large collections of spring wheat varieties and breeding lines of various origins [31-33].

In our work, the postulation of the genetic loci was made by comparing the GWAS results with published data on the chromosomal location of known $\mathrm{Sr}$ genes. The positions of loci at the chromosome were established in accordance with the consensus maps of hexaploid wheat constructed using a 90K SNP array. Significant marker-trait associations on chromosomes 6A and 6D were found in Tulaikovskaya-zolotistaya, Tulaikovskaya-10, Lutescens-101, Volgouralskaya and Kinelskaya-60 varieties, which displayed a high level of resistance in all years of trait evaluation (Table S1). According to the literature data, varieties Tulaikovskaya-zolotistaya, Tulaikovskaya-10 and Lutescens-101 contain the substitution of chromosome $6 \mathrm{D}$ on chromosome $6 \mathrm{Ai}=2$ from $\mathrm{Th}$. intermedium harboring genes for resistance to fungal diseases [34,35]. The resistance of these varieties to Pgt seems to be determined by the $S r 6 A i=2$ gene.

It has been suggested that the resistance of six varieties (Tulaikovskaya-belozernaya, Kinelskaya-60, Volgouralskaya, Erithrospermum-72, Albidum-73 and Strada-Siberi) is determined by the $5 r 25$ gene inherited from chromosome 7Ae\#1L of another wildgrass species Th. ponticum [36]. This is evidenced by associations with SNP markers located in the range from 126 to $211 \mathrm{cM}$ at the long arm of chromosome 7A. Additionally, Lr19 gene tightly linked to Sr 25 was previously obtained in the genome of Kinelskaya-60 and Volgouralskaya varieties [37].

SNP markers specific to chromosome $2 \mathrm{~B}$ showed associations with the resistance of all T. aestivum/T. timopheevii introgression lines and line 25-2 (T. aestivum/T. kiharae). The distribution of reliable MTAs along the length of the entire chromosome may indicate complete $2 \mathrm{~B} / 2 \mathrm{G}$ substitution in these genotypes. The results suggest that ILs contain the Sr36 gene introduced from T. timopheevii [38]. Genotypes with Sr36 gene are known to express high level of resistance to stem rust, including the Ug99 race $[39,40]$. The results of the field screening obtained in this work may also indicate the effectiveness of the Sr36 gene against the local Pgt population.

Marker trait associations at the long arm of chromosome 5B were detected in lines 25-2 and 34-1 (T. kiharae/Saratovskaya-29) and in T. aestivum/T. timopheevii lines, with the exception of ILs originating from the Irtyshanka-10 variety (Table 2). At the telomeric region of 5BL, two adult plant resistance genes were mapped—Sr49 (range 188.57-217.64 cM) and Sr56 (159.66-188.67 cM)—inherited from the winter wheat variety Arina and landrace variety Mahmoudi [41,42]. T. aestivum/T. timopheevii lines possessed a 5BS.5BL.5GL telomeric translocation with the LrTt2 gene [43]. It is possible that the translocation fragment harbors a new genetic factor from $5 \mathrm{G}$ chromosome of T. timopeevii and T. kiharae, which determines resistance to Pgt.

Significant MTAs were detected for three SNP located on chromosome 1A (Table 2). A set of QTLs at the long arm of $1 \mathrm{~A}$ chromosome were identified using mapping populations and GWAS [31,44]. However, the position of these loci does not coincide with the locus identified in this work. Sr1RSAmigo gene was introgressed into chromosome $1 \mathrm{~A}$ of bread wheat from rye Secale cereale [19]. The analysis of the pedigree of the varieties Omskaya-20, Priirtyshskaya-86 and Ustya indicates the participation of the cultivars Kavkaz and Bezostaya- 1 in their creation. This may be indirect evidence of the presence of the Sr1RS gene or its allele on chromosome 1A.

The long arm of chromosome 5A harbors QTL, located in the range of 89.56-93.75 cM. No stem rust resistance genes with constant symbols are currently mapped on chromosome 5A. Bajgain et al. [31] and Letta et al. [45] reported the presence of genetic factors for resistance to Pgt in this chromosome. However, the localization of these loci does not coincide with the QTL position established in our work.

Genetic factor on chromosome 7B was identified in the range 76.3-91.02 cM (Figure 4). According to data of various authors, the Sr17 gene was mapped in the diapason from 64.7 to $127 \mathrm{cM}$ using 
bi-parental mapping populations and GWAS [44,46,47]. This allowed us to suggest that the QTL at chromosome 7B may be the Sr17 gene.

At chromosome 2A, MTAs were detected for two SNPs located at a distance of $20 \mathrm{~cm}$ from each other. It is important to note that these loci are associated with the resistance of different genotypes: marker wsnp_Ex_c31900_40635609 was detected in ILs obtained from T. timopheevii and T. kiharae, the favorable allele of GENE-2352_964 was found in the genome of ILs containing alien chromatin from T. dicoccum and T. dicoccoides. Sr 21 gene originated from T. monococcum was mapped before at the long arm of chromosome $2 \mathrm{~A}[48,49]$. It is possible that alleles of this gene were introduced into the ILs from tetraploid relatives.

Two marker trait-associations were detected at the short arm of chromosome 3B. Chromosome 3BS bears the slow rusting gene $S r 2$; additionally, a number of QTLs was found at 3BS, which are probably to be $\operatorname{Sr} 2[31,44,45]$. In this study, QTL at 3BS was detected in wheat varieties, which displayed significant variability in stem rust severity from $5 R$ to $80 S$ during 2016-2017. Since the physiological marker of Sr2, known as "pseudo-black chaff" [50], was not phenotyped among these varieties, we hypothesized the novel QTL that could provide the slow rusting effect here. Taking into account that not only host resistance but environmental effect could result in slow-rusting, it is necessary to measure the area under the disease progress (AUDPC) before assuming the certain type of resistance for varieties.

\section{Materials and Methods}

\subsection{Plant Material and Phenotyping}

Plant material consisted of 158 wheat varieties, among them 105 spring wheat cultivars and advanced breeding lines adapted for cultivation to Siberian region, 53 introgression lines (ILs) and their parental forms (Table S1). Seeds of spring wheat cultivars and breeding lines, obtained from the National Genebank of Russian Federation (VIR, Federal Research Center N.I. Vavilov All-Russian Institute of Plant Genetic Resources, St. Petersburg, Russia; http://db.vir.nw.ru/virdb/maindb), were maintained and multiplied in The Federal Research Center Institute of Cytology and Genetics SB RAS (IC\&G SB RAS, Novosibirsk, Russia). Introgression lines were developed in the Institute of Cytology and Genetics SB RAS (Novosibirsk, Russia) and in the Institute of Genetics and Cytology (Minsk, Republic of Belarus) on the base of hybridization of spring bread wheat varieties with wild relatives (T. durum, T. dicoccum, T. dicoccoides and T. timopheevii) and synthetic hexaploid wheat T. kiharae [51,52]. The experimental plants were grown on the field of the Federal Research Center Institute of Cytology and Genetics SB RAS (Novosibirskaya oblast, $54.9191^{\circ}$ N, $82.9903^{\circ}$ E). Samples were sown in a randomized block design in two replicates on plots $1 \mathrm{~m}$ wide, 60 grains per row. Stem rust severity was evaluated against a natural infectious background during the summer season 2016-2018 (from June to August), from the onset of the first symptoms of the disease to the full development of the disease. Disease severity (SR) was estimated on a $0-100 \%$ modified Cobb scale [53]. Infection response (IT) was recorded as recommended by Roelfs et al. [1].

\subsection{Genotyping and Statistical Analysis}

Genomic DNA was isolated from 5-7-day-old seedlings as described in Kiseleva et al. [54]. Genotyping was carried out with the help of the Illumina Infinium 15K array of TraitGenetics GmbH (Gatersleben, Germany, www.traitgenetics.de), which included 13,006 SNP markers mapped in the wheat genome [23,24].

Analysis of variance (ANOVA) of the data on stem rust resistance in different environments was performed using the program STATISTICA v. 10 (www.statsoft.ru). The population structure (Q-matrix) was estimated using a Bayesian algorithm implemented in the program STRUCTURE 2.3.4 [55]. Q-matrix was calculated based on the results of genotyping with 4800 SNP markers. The number of suspected subclusters ranged from 1 to 10 . The simulation was performed using the admixture model; the number of runs was five with a burn-in length of 20,000 and Markov chain 
iterations of 50000. The most likely number of clusters was calculated from Delta $K(\Delta K)$ statistics [56] using the web-based program Structure Harvester [57]. Kinship (K) matrix was calculated using the program TASSEL V. 5.2.50 [58]. A complete set of SNP markers was used to calculate the K-matrix, with the exception of markers that showed missing data for all analyzed samples.

Marker-trait associations (MTAs) were determined on the basis of mixed linear model (MLM) with kinship matrix $(\mathrm{K})$ and population structure $(\mathrm{Q})$ as covariate using the program TASSEL v. 5.2.50. SNP markers with MAF (minor allele frequency) less than $5 \%$ and missing data $>10 \%$ were not included in the analysis. To identify reliable MTAs, Benjamini-Hochberg method [59] was used for controlling false discovery rate (FDR) of $p<0.05$. FDR was calculated by means of False Discovery Rate Online Calculator (https://tools.carbocation.com/FDR). The proposed genetic location of QTLs associated with stem rust resistance was determined using consensus maps of hexaploid wheat chromosomes presented by Wang et al. [23]. Chromosome maps were constructed with the MapChart version 2.3 software [60].

\section{Conclusions}

The results received in this study show the effectiveness of using GWAS to assess the genetic basis of resistance of wheat genotypes to stem rust pathogen. Obtained results allow us to estimate genetic protection level of cultivated spring wheat varieties and breeding germplasm. Nevertheless, it should be noted that, for a clear postulation of known and new resistance loci, additional analysis is needed using molecular markers developed for $\mathrm{Sr}$ genes. Moreover, to establish the chromosomal localization of target genes in the genome of donors containing alien translocations, cytological analysis is required. The obtained data can be considered as the initial stage for the selection of introgression lines with alien genetic material as sources of $\mathrm{Sr}$ loci.

Supplementary Materials: Supplementary materials can be found at http://www.mdpi.com/1422-0067/21/13/ 4706/s1.

Author Contributions: I.N.L. and E.A.S. carried out the experimental design of the research. I.N.L., E.S.S. and E.A.O. performed field experiments. I.N.L. conducted data analyses and prepared the draft version of the manuscript. O.A.O. contributed to the development of the introgression lines with T. durum, T. dicoccum and T. kiharae introgressions. All authors have read and approved the final version of the manuscript.

Funding: The phytopathological evaluation of the collection of spring wheat cultivars and GWAS were supported by Russian Science Foundation (project No. 16-16-00011). The part of the work performed with the collection of introgression lines was supported by the Russian Foundation for Basic Research (project 18-516-00001). The multiplication of the plant material was done in Laboratory of Artificial Plant Growth of IC\&G SB RAS within the budgetary project (No. 0324-2019-0039-C-01).

Conflicts of Interest: The authors declare no conflict of interest. The funders had no role in the design of the study; in the collection, analyses, or interpretation of data; in the writing of the manuscript, or in the decision to publish the results.

\section{Abbreviations}

$\begin{array}{ll}\text { ANOVA } & \text { Analysis of variance } \\ \text { GWAS } & \text { Genome-wide association study } \\ \text { ILs } & \text { Introgression lines } \\ \text { MAS } & \text { Marker assisted selection } \\ \text { MLM } & \text { Mixed linear model } \\ \text { MTA } & \text { Marker trait association } \\ \text { Pgt } & \text { Puccinia graminis f. sp. tritici } \\ \text { QTL } & \text { Quantitative trait locus } \\ \text { SR } & \text { severity rating } \\ \text { SNP } & \text { Single-nucleotide polymorphism } \\ \text { Sr gene } & \text { Stem rust resistance gene }\end{array}$




\section{References}

1. Roelfs, A.P.; Singh, R.P.; Saari, E.E. Rust Diseases of Wheat: Concepts and Methods of Disease Management; CIMMYT: Mexico city, Mexico, 1992.

2. Park, R.L. Stem rust of wheat in Australia. Aust. J. Agric. Res. 2007, 58, 558-566. [CrossRef]

3. Kolmer, J. Genetics of resistance to wheat leaf rust. Annu. Rev. Phytopathol. 1996, 34, 435-455. [CrossRef] [PubMed]

4. Campbell, C.L.; Long, D.L. The campaign to eradicate the common barberry in the United States. In Stem Rust of Wheat: From Ancient Enemy to Modern Foe; Peterson, P.D., Ed.; APS Press: St. Paul, MN, USA, 2001; pp. 16-50. ISBN 0890542716.

5. Saunders, D.G.O.; Pretorius, Z.A.; Hovmøller, M.S. Tackling the re-emergence of wheat stem rust in Western Europe. Commun. Biol. 2019, 2, 51. [CrossRef] [PubMed]

6. Singh, R.P.; Hodson, D.P.; Huerta-Espino, J.; Jin, Y.; Njau, P.; Wanyera, R.; Herrera-Foessel, S.A.; Ward, R.W. Will stem rust destroy the world's wheat crop. Adv. Agron. 2008, 98, 272-309. [CrossRef]

7. Wanyera, R.; Kinyua, M.G.; Jin, Y.; Singh, R. The spread of stem rust caused by Puccinia graminis f. sp. tritici with virulence on Sr31 in wheat in Eastern Africa. Plant Dis. 2006, 90, 113. [CrossRef] [PubMed]

8. Singh, R.P.; Hodson, D.P.; Huerta-Espino, J.; Jin, Y.; Bhavani, S.; Njau, P.; Herrera-Foessel, S.; Singh, P.K.; Singh, S.; Govindan, V. The emergence of Ug99 races of the stem rust fungus is a threat to world wheat production. Annu. Rev. Phytopathol. 2011, 49, 465-481. [CrossRef] [PubMed]

9. Singh, R.P.; Hodson, D.P.; Jin, Y.; Lagudah, E.S.; Ayliffe, M.A.; Bhavani, S.; Rouse, M.N.; Pretorius, Z.A.; Szabo, L.J.; Huerta-Espino, J.; et al. Emergence and spread of new races of wheat stem rust fungus: Continued threat to food security and prospects of genetic control. Phytopathology 2015, 105, 872-884. [CrossRef] [PubMed]

10. Skolotneva, E.S.; Lekomtseva, S.N.; Kosman, E. The wheat stem rust pathogen in the central region of the Russian Federation. Plant Pathol. 2013, 62, 1003-1010. [CrossRef]

11. Volkova, G.V.; Kudinova, O.A.; Miroshnichenko, O.O. Spread of stem rust in the North Caucasus and immunological characteristic of some winter wheat varieties with respect to the pathogen. Achiev. Sci. Technol. AIC 2018, 32, 43-45. [CrossRef]

12. Shamanin, V.P.; Pototskaya, I.V.; Shepelev, S.S.; Pozherukova, V.E.; Salina, E.A.; Skolotneva, E.S.; Hodson, D.; Hovmøller, M.; Patpour, M.; Morgounov, A.I. Stem rust in Western Siberia-race composition and effective resistance genes. Vavilov J. Genet. Breed. 2020, 24, 131-138. [CrossRef]

13. Lekomtseva, S.N.; Volkova, V.T.; Zaitseva, L.G.; Skolotneva, E.S.; Chaika, M.N. Analysis of virulence Puccinia graminis f. sp. tritici collected from different plant-host. Mikol. Fitopatol. 2007, 41, 554-563.

14. Vasilova, N.Z.; Askhadullin, D.-L.F.; Ashadullin, D.-R.F.; Bagavieva, E.Z.; Tazutdinova, M.R. Achieving the breeding of spring soft wheat in Tatarstan. Legumes Groat Crops. 2019, 2, 124-131. [CrossRef]

15. Lapochkina, I.F.; Baranova, O.A.; Shamanin, V.P.; Volkova, G.V.; Gainullin, N.R.; Anisimova, A.V.; Galinger, D.N.; Lazareva, E.N.; Gladkova, E.V.; Vaganova, O.F. The development of initial material of spring common wheat for breeding for resistance to stem rust (Puccinia graminis Pers. f. sp. tritici) including race Ug99, in Russia. Vavilov J. Genet. Breed. 2016, 20, 320-328. [CrossRef]

16. Maltseva, L.T.; Filippova, E.A.; Bannikova, N.Y.; Berdyugin, V.A. The role of the initial material in breeding of the spring soft wheat varieties resistant to rust in Zauralye. Grain Econ. Russ. 2018, 5, 67-72. [CrossRef]

17. Rsaliyev, A.S.; Rsaliyev, S.S. Principal approaches and achievements in studying race composition of wheat stem rust. Vavilov J. Genet. Breed. 2018, 22, 967-977. [CrossRef]

18. Skolotneva, E.S.; Kelbin, V.N.; Morgunov, A.I.; Boiko, N.I.; Shamanin, V.P.; Salina, E.A. Races composition of the Novosibirsk population of Puccinia graminis f. sp. tritici. Mikol. Fitopatol. 2020, 54, 49-58. [CrossRef]

19. McIntosh, R.A.; Yamazaki, Y.; Dubcovsky, J.; Rogers, W.J.; Morris, C.; Appel, S.; Xia, X.C. Catalogue of Gene Symbols for Wheat. 2013. Supplements 2014-2017. Available online: http://shigen.nig.ac.jp/wheat/komugi/ genes/ (accessed on 16 June 2020).

20. Rouse, M.N.; Wanyera, R.; Njau, P.; Jin, Y. Sources of resistance to stem rust race Ug99 in spring wheat germplasm. Plant Dis. 2011, 95, 762-766. [CrossRef] [PubMed]

21. Kimani, N.C.; Onguso, J.; Njau, P. Screening of Kenyan bread wheat varieties for resistance to the emerging strains of stem rust fungi (Puccinia graminis f. sp. tritici) race Ug99. World J. Agricult. Res. 2015, 3, 5-10. [CrossRef] 
22. Baranova, O.A.; Sibikeev, S.N.; Druzhin, A.E. Molecular identification of the stem rust resistance genes in the introgression lines of spring bread wheat. Vavilov J. Genet. Breed. 2019, 23, 296-303. [CrossRef]

23. Wang, S.; Wong, D.; Forrest, K.; Allen, A.; Chao, S.; Huang, B.E.; Maccaferri, M.; Salvi, S.; Milner, S.G.; Cattivelli, L.; et al. Characterization of polyploid wheat genomic diversity using a high-density 90,000 single nucleotide polymorphism array. Plant Biotechnol. J. 2014, 12, 787-796. [CrossRef]

24. The Triticeae Tollbox. Available online: https://triticeaetoolbox.org/ (accessed on 3 June 2020).

25. Gerard, G.S.; Börner, A.; Lohwasser, U.; Simón, M.R. Genome-wide association mapping of genetic factors controlling Septoria tritici blotch resistance and their association with plant height and heading date in wheat. Euphytica 2017, 213, 27-41. [CrossRef]

26. Kankwatsa, P.; Singh, D.; Thomson, P.C.; Bonman, J.M.; Newcomb, M.; Park, R.K. Characterization and genome-wide association mapping of resistance to leaf rust, stem rust and stripe rust in a geographically diverse collection of spring wheat landraces. Mol. Breed. 2017, 37, 113-136. [CrossRef]

27. Winfield, M.O.; Allen, A.M.; Wilkinson, P.A.; Burridge, A.J.; Barker, G.L.A.; Coghill, J.; Waterfall, C.; Wingen, L.U.; Griffiths, S.; Edwards, K.J. High-density genotyping of the A.E. Watkins Collection of hexaploid landraces identifies a large molecular diversity compared to elite bread wheat. Plant. Biotechnol. J. 2018, 16, 165-175. [CrossRef] [PubMed]

28. Li, F.; Wen, W.; Liu, J.; Zhang, Y.; Cao, S.; He, Z.; Rasheed, A.; Jin, H.; Zhang, C.; Yan, J.; et al. Genetic architecture of grain yield in bread wheat based on genome-wide association studies. BMC Plant Biol. 2019, 19, 168. [CrossRef] [PubMed]

29. Gao, L.; Turner, M.K.; Chao, S.; Kolmer, J.; Anderson, J.A. Genome wide association study of seedling and adult plant leaf rust resistance in elite spring wheat breeding lines. PLoS ONE 2016, 11, e0148671. [CrossRef]

30. Turner, M.K.; Kolmer, J.A.; Pumphrey, M.O.; Bulli, P.; Chao, S.; Anderson, J.A. Association mapping of leaf rust resistance loci in a spring wheat core collection. Theor. Appl. Genet. 2017, 130, 345-361. [CrossRef]

31. Bajgain, P.; Rouse, M.N.; Bulli, P.; Bhavani, S.; Gordon, T.; Wanyera, R.; Njau, P.N.; Legesse, W.; Anderson, J.A.; Pumphrey, M.O. Association mapping of North American spring wheat breeding germplasm reveals loci conferring resistance to Ug99 and other African stem rust races. BMC Plant Biol. 2015, 15, 249. [CrossRef]

32. Pasam, R.K.; Bansal, U.; Daetwyler, H.D.; Forrest, K.L.; Wong, D.; Petkowski, J.; Willey, N.; Randhawa, M.; Chhetri, M.; Miah, H.; et al. Detection and validation of genomic regions associated with resistance to rust diseases in a worldwide hexaploid wheat landrace collection using BayesR and mixed linear model approaches. Theor. Appl. Genet. 2017, 130, 777-793. [CrossRef]

33. Edae, E.A.; Pumphrey, M.O.; Rouse, M.N. A genome-wide association study of field and seedling response to individual stem rust pathogen races reveals combinations of race-specific genes in North American spring wheat. Front. Plant Sci. 2018, 9, 52. [CrossRef]

34. Salina, E.A.; Adonina, I.G.; Badaeva, E.D.; Kroupin, P.Y.; Stasuyk, A.I.; Leonova, I.N.; Shishkina, A.A.; Divashuk, M.G.; Starikova, E.V.; Khuat, T.M.L.; et al. Thinopyrum intermedium chromosome in bread wheat cultivars as a source of genes conferring resistance to fungal diseases. Euphytica 2015, 204, 91-101. [CrossRef]

35. Leonova, I.N. Genome-wide association study of powdery mildew resistance in Russian spring wheat (T. aestivum L.) varieties. Rus. J. Genet. 2019, 55, 1360-1374. [CrossRef]

36. McIntosh, R.A.; Dyck, P.L.; Green, G.J. Inheritance of leaf rust and stem rust resistances in wheat cultivars Agent and Agatha. Aust. J. Agric. Res. 1977, 28, 37-45. [CrossRef]

37. Morgounov, A.; Ablova, I.; Babayants, O.; Babayants, L.; Bespalova, L.; Khudokormov, Z.; Litvinenko, N.; Shamanin, V.; Syukov, V. Genetic protection of wheat from rusts and development of resistant varieties in Russia and Ukraine. Euphytica 2011, 179, 297-311. [CrossRef]

38. Tsilo, T.J.; Jin, Y.; Anderson, J.A. Diagnostic microsatellite markers for the detection of stem rust resistance gene Sr36 in diverse genetic backgrounds of wheat. Crop. Sci. 2008, 48, 253-261. [CrossRef]

39. Jin, Y.; Szabo, L.J.; Rouse, M.N.; Fetch, T., Jr.; Pretorius, Z.A.; Wanyera, R.; Njau, P. Detection of virulence to resistance gene Sr36 within the TTKS race lineage of Puccinia graminis f. sp. tritici. Plant Dis. 2009, 93, 367-370. [CrossRef] [PubMed]

40. Purnhauser, L.; Bóna, L.; Láng, L. Identification of Sr31 and Sr36 stem rust resistance genes in wheat cultivars registered in Hungary. Cereal Res. Commun. 2011, 39, 53-66. [CrossRef]

41. Bansal, U.; Bariana, H.; Wong, D.; Randhawa, M.; Wicker, T.; Hayden, M.; Keller, B. Molecular mapping of an adult plant stem rust resistance gene Sr56 in winter wheat cultivar Arina. Theor. Appl. Genet. 2014, 127, 1441-1448. [CrossRef] [PubMed] 
42. Bansal, U.K.; Muhammad, S.; Forrest, K.L.; Hayden, M.J.; Bariana, H.S. Mapping of a new stem rust resistance gene Sr49 in chromosome 5B of wheat. Theor. Appl. Genet. 2015, 28, 2113-2119. [CrossRef]

43. Leonova, I.N.; Budashkina, E.B.; Flath, K.; Weidner, A.; Börner, A.; Röder, M.S. Microsatellite mapping of a leaf rust resistance gene transferred to common wheat from Triticum timopheevii. Cereal Res. Commun. 2010, 38, 211-219. [CrossRef]

44. Yu, L.X.; Lorenz, A.; Rutkoski, J.; Singh, R.P.; Bhavani, S.; Huerta-Espino, J.; Sorrells, M.E. Association mapping and gene-gene interaction for stem rust resistance in CIMMYT spring wheat germplasm. Theor. Appl. Genet. 2011, 123, 1257-1268. [CrossRef]

45. Letta, T.; Maccaferri, M.; Badebo, A.; Ammar, K.; Ricci, A.; Crossa, J.; Tuberosa, R. Searching for novel sources of field resistance to Ug99 and Ethiopian stem rust races in durum wheat via association mapping. Theor. Appl. Genet. 2013, 126, 1237-1256. [CrossRef]

46. Bansal, U.K.; Bossolini, E.; Miah, H.; Keller, B.; Park, R.F.; Bariana, H.S. Genetic mapping of seedling and adult plant stem rust resistance in two European winter wheat cultivars. Euphytica 2008, 164, 821-828. [CrossRef]

47. Yu, L.X.; Chao, S.; Singh, R.P.; Sorrells, M.E. Identification and validation of single nucleotide polymorphic markers linked to Ug99 stem rust resistance in spring wheat. PLoS ONE 2017, 12, e0171963. [CrossRef] [PubMed]

48. Spielmeyer, W.; Sharp, P.J.; Lagudah, E.S. Identification and validation of markers linked to broad-spectrum stem rust resistance gene $S r 2$ in wheat (Triticum aestivum L.). Crop. Sci. 2003, 43, 333-336. [CrossRef]

49. Chen, S.; Rouse, M.N.; Zhang, W.; Jin, Y.; Akhunov, E.; Wei, Y.; Dubcovsky, J. Fine mapping and characterization of Sr21, a temperature-sensitive diploid wheat resistance gene effective against the Puccinia graminis f. sp. tritici Ug99 race group. Theor. Appl. Genet. 2015, 128, 645-656. [CrossRef]

50. Brown, G.N. The inheritance and expression of leaf chlorosis associated with gene Sr2 for adult plant resistance to wheat stem rust. Euphytica 1997, 95, 67-71. [CrossRef]

51. Orlovskaya, O.A.; Koren, L.V.; Khotyleva, L.V. Cytological characteristic of wheat hybrids produced by remote hybridization in the Triticeae tribe. Proc. Natl. Acad. Sci. Belarus 2010, 4, 50-54.

52. Leonova, I.N.; Budashkina, E.B.; Kalinina, N.P.; Röder, M.S.; Börner, A.; Salina, E.A. Triticum aestivum $\mathrm{x}$ Triticum timopheevii introgression lines as a source of pathogen resistance genes. Czech J. Genet. Plant Breed. 2011, 47, S49-S55. [CrossRef]

53. Peterson, R.F.; Campbell, A.B.; Hannah, A.E. A diagrammatic scale for estimating rust intensity on leaves and stems of cereals. Can. J. Res. 1948, 26, 496-500. [CrossRef]

54. Kiseleva, A.A.; Shcherban, A.B.; Leonova, I.N.; Frenkel, Z.; Salina, E.A. Identification of new heading date determinants in wheat 5B chromosome. BMC Plant Biol. 2016, 16, 8. [CrossRef]

55. Pritchard, J.; Stephens, M.; Donnelly, P. Inference of population structure using multilocus genotype data. Genetics 2000, 155, 945-959. [PubMed]

56. Evanno, G.; Regnaut, S.; Goudet, J. Detecting the number of clusters of individuals using the software STRUCTURE: A simulation study. Mol. Ecol. 2005, 14, 2611-2620. [CrossRef] [PubMed]

57. Earl, D.A.; VonHoldt, B.M. STRUCTURE HARVESTER: A website and program for visualizing STRUCTURE output and implementing the Evanno method. Conserv. Genet. Resour. 2012, 4, 359-361. [CrossRef]

58. Bradbury, P.J.; Zhang, Z.; Kroon, D.E.; Casstevens, T.M.; Ramdoss, Y.; Buckler, E.S. TASSEL: Software for association mapping of complex traits in diverse samples. Bioinformatics 2007, 23, 2633-2635. [CrossRef]

59. Benjamini, Y.; Hochberg, Y. Controlling the false discovery rate: A practical and powerful approach to multiple testing. J. R. Statist. Soc. Ser. B Methodol. 1995, 57, 289-300. [CrossRef]

60. Voorrips, R.E. MapChart: Software for the graphical presentation of linkage maps and QTLs. J. Hered. 2002, 93, 77-78. [CrossRef]

(C) 2020 by the authors. Licensee MDPI, Basel, Switzerland. This article is an open access article distributed under the terms and conditions of the Creative Commons Attribution (CC BY) license (http://creativecommons.org/licenses/by/4.0/). 